\title{
Sex Differences in Immunity to Viral Infections
}

\author{
Henning Jacobsen and Sabra L. Klein* \\ W. Harry Feinstone Department of Molecular Microbiology and Immunology, The Johns Hopkins Bloomberg School of Public \\ Health, Baltimore, MD, United States
}

The ongoing COVID-19 pandemic has increased awareness about sex-specific differences in immunity and outcomes following SARS-CoV-2 infection. Strong evidence of a male bias in COVID-19 disease severity is hypothesized to be mediated by sex differential immune responses against SARS-CoV-2. This hypothesis is based on data from other viral infections, including influenza viruses, HIV, hepatitis viruses, and others that have demonstrated sex-specific immunity to viral infections. Although males are more susceptible to most viral infections, females possess immunological features that render them more vulnerable to distinct immune-related disease outcomes. Both sex chromosome complement and related genes as well as sex steroids play important roles in mediating the development of sex differences in immunity to viral infections.

\section{OPEN ACCESS}

Edited by:

Ikuo Shoii,

Kobe University, Japan

Reviewed by:

Jason Kindrachuk,

University of Manitoba, Canada

Enrique Martin-Gayo,

Fundación de la Universidad

Autónoma de Madrid, Spain

*Correspondence:

Sabra L. Klein

sklein2@jhu.edu

Specialty section:

This article was submitted to

Viral Immunology,

a section of the journal

Frontiers in Immunology

Received: 05 June 2021

Accepted: 11 August 2021

Published: 31 August 2021

Citation:

Jacobsen $H$ and Klein SL (2021) Sex Differences in Immunity to Viral Infections.

Front. Immunol. 12:720952. doi: 10.3389/fimmu.2021.720952
Keywords: inflammation, innate immunity, T cells, antibodies, SARS-CoV-2, influenza

\section{INTRODUCTION}

The ongoing coronavirus infectious disease 2019 (COVID-19) pandemic has raised awareness about sex-specific differences in immunity against severe acute respiratory syndrome coronavirus 2 (SARS-CoV-2) infection. Although individual countries report sex biases in rates of confirmed infections (1) on a global scale, infection rates appear to be similar between males and females (2). A more consistent observation across diverse countries and cultures is that severe COVID-19 is more likely to occur in males than females (3-8). Male COVID-19 patients are twice as likely to require ICU admission and are 30\% more likely to die due to COVID-19 compared to female patients (9). Sex differences in outcomes of viral infections are not limited to SARS-CoV-2 and numerous clinical and epidemiological studies have provided evidence that biological sex broadly affects immunity to viral infection (10-12). Infections with viruses, such as Dengue virus, hantaviruses, and hepatitis $B$ $(\mathrm{HBV})$ and $\mathrm{C}(\mathrm{HCV})$ viruses, are more prevalent in human males than females suggesting that behavioral or occupational exposures contribute (13-17). The intensity and severity of disease caused by some viruses, including but not limited to Epstein Barr virus, HBV, HCV, and West Nile virus, are also greater for males than females (16-21). There are, however, some viruses that are more prevalent in females than males, such as cytomegalovirus, herpes simplex virus type 2 (HSV2), and human T-cell leukemia virus type 1 (22-25), and that cause more severe disease following infection, including hantaviruses, HSV2, human immunodeficiency virus (HIV), pandemic influenza A viruses (IAVs), and measles virus $(14,23,24,26-29)$. With regard to beta coronaviruses specifically, in addition to SARS-CoV-2, being male is a risk factor for more severe disease following infection with both SARS-CoV and middle-east respiratory syndrome virus (MERS) (30-33). 
Sex differences in disease outcomes are not limited to infectious diseases but are also observed in outcomes of autoimmune diseases and cancers, for example. While males have a higher incidence of non-reproductive cancer and are generally more susceptible to severe outcomes from a broad variety of pathogens, including bacterial, parasitic, fungal and viral infections $(10,11,34)$, females are more likely suffer from autoimmune disorders, including systemic lupus erythematosus and multiple sclerosis $(35,36)$. Inflammatory diseases, including those of the skin, respiratory, and gastrointestinal tract, also are more prevalent among adult females than males (37-43). Sex as a biological variable not only affects outcomes of diverse diseases but also impacts drug and vaccine efficacy (44). The latter being especially important in the context of the ongoing COVID-19 pandemic and world-wide SARS-CoV-2 immunization roll out (45-48).

\section{THE DIFFERENCES BETWEEN BIOLOGICAL SEX AND GENDER}

The terms 'sex' and 'gender' are often used interchangeably and, therefore, incorrectly. Sex refers to biological features that differ between males and females as a result of sex chromosome complement, the development of reproductive tissues, and concentration of sex steroids. Sex differences are often analyzed as a binary variable (i.e., male/XY vs. female/XX), but intersex individuals (i.e., individuals born with reproductive characteristics of both males and females) as well as Turner syndrome (i.e., XO individuals) and Kleinfelder's syndrome (i.e., XXY individuals) patients provide evidence that sex occurs on a continuum, which deserves greater empirical consideration in the context of infectious diseases. Sex differences can affect the control and clearance of viruses which is primarily mediated by the immune responses initiated and the pathology that may occur following infection, which will be the focus of this review (Figure 1). Although not the focus of this review, anatomical sex differences in the genital tract are associated with increased transmission of certain pathogens, including sexually transmitted viruses, in females compared with males $(38,49)$.

Gender differences are reflected in the social-cultural construct of being a man, woman, or transgender (27). Gender differences reflect behaviour, cultural, and social factors that in the context of infectious diseases might impact exposures, access, and decision making about care or treatments. In a majority of individuals, biological sex (male or female) matches the subject's gender (man or woman), with the biomedical implications of being transgender not thoroughly evaluated in the context of infectious diseases, including COVID-19. Other than consideration of whether transgender individuals trust of the medical establishment in the context of SARS-CoV-2 testing, COVID-19 treatment, and receipt of SARS-CoV-2 vaccines (50) as well as how receipt of gender-confirming hormone treatments and surgical procedures have been affected by the pandemic (51), there have been no reports comparing cis and transgender individuals in terms of infection rates or outcomes of either infection or vaccination against SARS-CoV-2. There also has been little to no COVID-19 tracking of data from transgender individuals at either country to state levels (9), which is a missed opportunity. There is, however, a call to include transgender individuals in studies evaluating the impact of sex steroids on COVID-19 outcomes (52).

Binary gender differences have been primarily characterized in the behaviors, occupations, and attitudes that impact risk of exposure to viruses, care-seeking behaviors, as well as access to care and reporting $(11,34)$. Importantly, cultural differences across the world may result in inconsistent or even contradictory observations about gender-specific differences in viral infections (53). Additionally, because sex and gender intersect, it is difficult to ascribe differential outcomes from viral infections in humans to either sex or gender. This is where animal models and primary cell culture systems can be integral for interpretations related to biological sex (54). Sex and gender further intersect with other demographic variables and comorbidities to influence viral infection outcomes. Obesity, for example, is more prevalent in females compared to males and is often linked to impaired immunity $(55,56)$. Male-female differences in the outcome of viral infections are also significantly affected by age as a result of genetic modifications as well as changing sex steroid concentrations throughout different stages of life (57). Females generally live longer than males, with increased frailty at older ages in females compared to males $(58,59)$. A longer life-span in females provides a natural bias in infection rates in this age group. Despite age-related changes in sex steroids, postmenopausal females remain immune-privileged even after the decline in sex steroid hormone concentration, suggesting genetic mechanisms are involved (58). Although the decline of sex steroids with age is more pronounced in females than males, the age-related decline of functional immunity paralleling this is slower in females compared to males $(57,60)$. An intersectional analysis provides a deeper understanding of the causes of differences between males and females in viral infection outcomes (61).

\section{IMMUNOLOGICAL DIFFERENCES BETWEEN THE SEXES}

Several studies have shown that innate and adaptive immune responses are generally greater in females than males across diverse species $(22,34,62,63)$. The activity of innate immune cells, such as macrophages and dendritic cells (DCs), as well as the overall inflammatory response is generally greater in females than males, particularly during reproductive ages $(62,64)$. In humans, cytokine production following ex vivo stimulation of monocytes with lipopolysaccharide (LPS) is greater in cells from males than females, with evidence that hormone-based contraceptive use in females further reduces the production of cytokines, including IFN $\gamma$ and TNF $\alpha$ (65). In response to SARS-CoV infection, male mice experience more severe outcomes within one week of infection, which corresponds with a more dramatic infiltration of inflammatory monocytes 


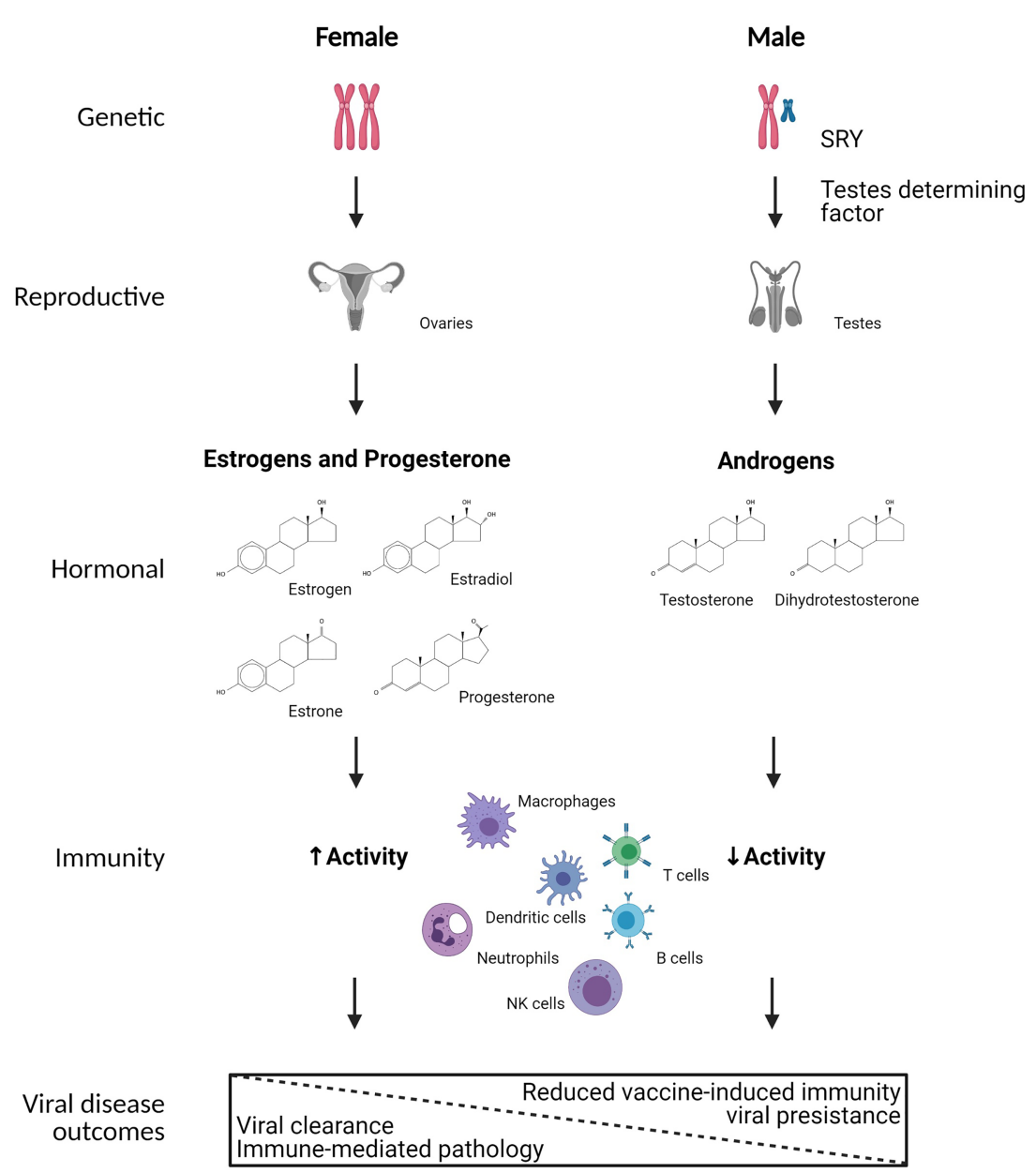

FIGURE 1 | Mechanistic causes of sex differences in immunity to viral infection. Biological sex is defined by sex chromosome complement (i.e., XX or XY) in a majority of individuals, which results in sex differential development of gonadal tissues in utero, with development of ovaries in XX individuals and testes in $X Y$ individuals. The development of testes in XY individuals is primarily mediated by the expression of SRY on the $Y$ chromosome, which encodes for testes determining factor. The ovaries and testes secrete differential concentrations of sex steroids, including estrogens, progesterone, and androgens. Numerous immune cells, including but not limited to macrophages, dendritic cells, neutrophils, NK cells, T cells, and B cells express cytoplasmic receptors for sex steroids, which can transcriptionally regulate gene expression, signal transduction, and responses of immune cells following viral infection. As a result, biological females tend to have greater immune system activation resulting in faster clearance of viruses, but also increased probability of developing immune-mediated pathology. In biological males, reduced immune system activation results in slower clearance of viruses, and in some cases viral persistence as well as reduced vaccine-induced immunity. Created using Biorender.

and neutrophils into the lungs of males as compared with females (66). Depletion of inflammatory monocytes in males resulted in SARS-CoV outcomes that are similar to females (66). Testosterone dampens infiltration of inflammatory monocytes and pulmonary inflammation during IAV infection (67). Macrophages from males are also more susceptible to infection with HIV-1 than are macrophages from females, which is at least partially caused by reduced virus restriction by SAMHD1 (i.e., SAM and HD domain containing deoxynucleoside triphosphate triphosphohydrolase 1) in cells from male donors (68). Plasmacytoid dendritic cells (pDCs) isolated from human females show greater expression of the X-linked gene, TLR7, and type 1 IFNs than pDCs from males, which is mediated by TLR7 escape from X chromosome inactivation (69). Sex-based differences are reported in innate immune responses of pDCs to HIV-1-encoded TLR7 ligands, in which pDCs from HIV-1 infected women produce significantly more IFN $\alpha$ and show greater expression of interferon stimulated genes (ISGs), including interferon regulatory factor 5 (IRF5) than pDCs from HIV-1 infected men following ex vivo stimulation (70-72)

Females also have greater $\mathrm{CD}^{+}$and $\mathrm{CD}^{+}{ }^{+} \mathrm{T}$-cell counts as well a higher $\mathrm{CD} 4^{+} / \mathrm{CD}^{+}$ratio compared to males, whereas frequencies of $\mathrm{CD}^{+} \mathrm{T}$ cells and NK cells are greater in males (73-78). Activity of both $\mathrm{CD}^{+}$and $\mathrm{CD}^{+} \mathrm{T}$ cells following stimulation is often greater in females than males $(63,72,79)$. Additionally, antigen-presenting cells (APC) in female mice are reported to be more efficient in antigen presentation compared to APCs from male mice (80). Adult females present an immune 
response that is biased towards a more pro-inflammatory $\mathrm{T}_{\mathrm{H}} 1$ cytokine milieu while adult males show a predominant $\mathrm{T}_{\mathrm{H}} 2$ phenotype with increased frequencies of regulatory $\mathrm{T}$ cells $\left(\mathrm{T}_{\text {reg }}\right)$ $(22,73,81,82)$. Adult females also have higher B-cell frequencies compared to males $(74,78)$. Basal levels and antibody response to viruses and vaccination also are greater in females than males (83-86). Because the pathogenesis of viruses is affected by both the hosts immune response and the virus, greater immunity among females can both be a cause and a consequence of viral disease (11). Specifically, the immune responses necessary to control virus replication, if excessive can cause immune-mediated pathology and tissue damage. While control of virus replication is often superior in females (e.g., HBV, HCV, and HIV), females also may experience more severe immune-mediated pathology (e.g., IAV and HIV) (11). A notable exception is SARS-CoV-2, in which males shed virus for a longer duration of time $(87,88)$ and present with greater inflammation (89) than females.

During SARS-CoV-2 infection, it has been reported that males present higher pro-inflammatory cytokine expression, including IL-6, than females (90, 91). While COVID-19 is known to cause lymphopenia in both sexes, $\mathrm{T}$ cell frequencies and activation remains greater in females than males during SARS-CoV-2 infection, even at older ages $(91,92)$. In contrast, male sex is associated with greater anti SARS-CoV-2 antibody production in convalescent patients $(91,93,94)$ as well as fewer breakthrough SARS-CoV-2 infections following vaccination (95). Females have greater antibody responses to the mRNA SARS-Cov-2 vaccines than males (96).

\section{SEX STEROIDS DIRECTLY AFFECT IMMUNITY TO VIRUSES}

Sex differences in immunity are often most pronounced in aged matched males and pre-menopausal females, with age-associated reductions in sex steroid concentrations paralleling changes in functional immunity $(57,58)$. Multiple mechanisms have been described for how sex steroids affect immune function directly and differentially in females and males. Sex steroids have been shown to directly affect gene expression on an epigenetic level $(97,98)$. Even viruses can directly interact with sex steroids; for example, HCV contains a progesterone response element suggesting that this virus can be regulated by the progesterone receptor (99).

Sex steroids affect the functioning of immune cells by binding to cytoplasmic receptors and interacting with nuclear hormone response elements (HRE) (100). Many genes involved in antiviral immunity, like IFNG and IRF5, possess estrogen response elements $(63,101,102)$, and sex steroid mediated activation of HREs can directly result in increased cytokine and chemokine production (100). Expression of immune-regulatory miRNAs also can be under hormonal control (103). Estrogen receptors (ER) are differentially expressed among different immune cell subsets, with higher expression of ER $\alpha$ reported in T cells and high expression of ER $\beta$ found in B cells (102). In addition to classical nuclear signaling, non-classical ER signaling can affect many immune-related pathways, including through transcriptional regulation of NF- $\mathrm{BB}$ (104). Estrogens can have dose-dependent and bipotential effects on many immune cells (105-108). For example, estradiol (E2) affects the cytotoxicity of NK cells, activation and differentiation of monocytes, macrophages and dendritic cells, in a dose-dependent manner (109-112). Generally, low (non-pregnant) concentrations of E2 are thought to promote a $\mathrm{T}_{\mathrm{H}} 1$-based immune response, whereas high (pregnancy) E2 concentration, can drive the immune response more towards $\mathrm{T}_{\mathrm{H}} 2$ immunity (107). This is further supported by the fact that E2 at pregnancy doses enhances $\mathrm{T}_{\mathrm{Reg}}$ proliferation (113). E2 induces somatic hypermutation and antibody class switching, with humoral responses to viral infection being greater in the presence as opposed to the absence of E2 (108, 114, 115).

Progesterone (P4) typically skews the immune profile of females from $\mathrm{T}_{\mathrm{H}} 1$ to either $\mathrm{T}_{\mathrm{H}} 2$ or $\mathrm{T}_{\text {reg }}$ immunity $(116,117)$. Progesterone receptors are found on many different immune cells, including T-cells, NK-cells, macrophages, and DCs (118). Progesterone reduces macrophage activation and production of pro-inflammatory cytokines in rodents and can antagonize TLRsignaling and signaling pathways involving NF- $\mathrm{KB}$ (119). Progesterone also dampens inflammation and promotes amphiregulin and Th17-mediated tissue repair after viral infection at mucosal sites, including the respiratory tract (120). As a result, P4-based therapies and contraceptives have been reported to reduce susceptibility to IAV infection, at last in mice $(120,121)$.

Androgens, in particular testosterone (T), are generally antiinflammatory. Testosterone can decrease NK cell, neutrophil, and macrophage activity in vitro resulting in reduced production of pro-inflammatory cytokines, such as TNF- $\alpha$ and reactive oxygen species (e.g., iNOS and NO) (122-124). Testosterone can also increase the production of anti-inflammatory cytokines, such as IL-10 and TGF- $\beta$ via androgen receptor signaling (124, 125). Production of anti-inflammatory cytokines (e.g., IL-10) after TLR9 activation, which is the pattern recognition receptor used for detection of DNA viruses, is greater in males and this effect positively correlates with androgen concentrations (126). Antibody response to vaccination are repeatedly described to be lower in males compared to females (83), with a T-sensitive gene cluster identified to correlate with lower vaccine-induced antibody responses in males (85).

The immunomodulatory function of $\mathrm{T}$ is most convincing in experimental studies in which $\mathrm{T}$ is removed and replaced exogenously. In the context of infection with IAV, T dampens pulmonary inflammation, including frequencies of inflammatory monocytes, eosinophils, and virus-specific CD8+ T cells after virus has been cleared (67). This effect is reversed by gonadectomy (i.e., surgical removal of the testes) or cotreatment of an androgen receptor antagonist in combination with $\mathrm{T}$. In the context of vaccination, gonadectomy increases whereas treatment of gonadectomized male mice with $\mathrm{T}$ reduces vaccine-induced antibody responses (115). Aging is associated with reduced concentrations of $\mathrm{T}$ in male rodents and humans (115). Treatment of aged male mice with $\mathrm{T}$ improves the outcome of infection of IAV primarily by dampening 
inflammation as opposed to altering antiviral immunity and virus replication (127). Taken together there is growing evidence that immunity to viruses and vaccines is impacted by the concentrations of sex steroid hormones and signaling through their respective receptors, which impacts the outcome of viral infections differently for males and females over the life course, and in females with pregnancy.

\section{GENETIC FACTORS CONTRIBUTE TO SEX DIFFERENCES IN IMMUNITY TO VIRUSES}

Multiple studies highlight a significant role of sex chromosome complement on overall immunity $(11,128,129)$. Many genes with immunomodulatory function are encoded on the $\mathrm{X}$ chromosome (130). The XX complement provides females with two copies of $\mathrm{X}$ chromosomes, one derived from the father and one derived from the mother. To compensate for gene dosage effects, one $\mathrm{X}$ chromosome is randomly inactivated in every single cell of a female. As this happens randomly, females show an X-chromosome mosaicism that provides many advantages compared to the XY complement. Disadvantageous mutations in one X-chromosome possibly affecting immune function will only affect half of the cells in a female, but necessarily all cells in a male. Furthermore, the XX chromosome complement provides females with additional allelic diversity that was hypothesized to be another advantage when facing new immune challenges (131133). Genetic disorders like Klinefelter syndrome, resulting in males having an additional $\mathrm{X}$ chromosome (XXY) result in immune responses that are more similar to the typical female than male phenotype (134). Additionally, Turner's syndrome, resulting in females with only one $\mathrm{X}$ chromosome (X0), is associated with lower lymphocyte counts and reduced antibody production in females (135). Sex chromosome complement is associated with multiple sex differences in diverse organs, even before gonadal development (129).

The $\mathrm{X}$ chromosomes encode for several immune-related genes such as TLR7, IRAK1, FOXP3 as well as many miRNAs that are important for immune system gene regulation (136). Certain regions of the $\mathrm{X}$-chromosome may escape inactivation with a direct effect on dosage compensation of X-linked immune genes $(136,137)$. TLR7, which is important for sensing RNAviruses, is encoded on the X-chromosome and TLR7 expression levels as well as immune sensing of RNA antigens, including virus vaccine and self-antigens are stronger in females $(137,138)$. Studies in the context of systemic lupus erythematosus show that substantial fractions of immune cells, including primary B lymphocytes, monocytes, and DCs express TLR7 from both Xchromosomes, resulting in higher TLR7-driven functional responses in these cells $(139,140)$. Furthermore, TLR7 is an important mediator of $B$ cell maturation and therefore antibody production (141). Greater expression of TLR7 in B cells from females compared with males consequently is associated to greater antiviral antibody responses following receipt of the influenza vaccine in mice (142). In contrast, deleterious mutations in TLR7, which are only observed among males, can be associated with increased susceptibility to viral infections, including with SARS-CoV-2 (143). In addition to genes, a disproportionally high number of miRNAs is encoded on the X-chromosome (i.e., 10\% of all miRNAs encoded in the human genome). In contrast, the Y-chromosome only encodes for two known miRNAs (144-146). There is evidence supporting that X-linked miRNAs are indeed a significant contributor to sex-differences in immunity (144).

Only biological males can be affected by $\mathrm{Y}$ chromosome (ChrY) polymorphisms, which can result in aberrated expression of immune-related genes $(147,148)$. This has primarily been studied in the context of autoimmunity, but also has implications on immunity to viral infections, including coxsackievirus and IAV (149). Strains of ChrY consomic mice have been used to show that variation in ChrY affects survival of male mice after IAV infection, which is associated with increased frequencies and activation of IL-17-producing $\gamma \delta \mathrm{T}$ cells that are linked to acute lung injury during IAV infection (150, 151). Polymorphisms in ChrY can affect global gene expression in immune cells through epigenetically mechanisms (149). The effect of ChrY polymorphisms on IAV pathogenesis are independent of sex steroids, underpinning the mechanistical features of genetic effects on sex-differences in immunity (152). Another important mechanism associated to the XY complement is loss of the $\mathrm{Y}$ chromosomes (LOY) primarily in leukocytes during aging, leading to widespread dysregulation of autosomal genes among leukocytes in men with possible implications on immunity (153155). Taken together, sex chromosome complement, activity of regulatory elements on sex chromosomes, and the expression of sex chromosomal genes contribute to sex differences in immunity to viral infections.

\section{SEX DIFFERENCES IMMUNITY BEGIN IN UTERO}

Sex differential mechanisms that are likely independent of sex steroids are also found in peri- and postnatal immunity and epigenetic imprinting during in utero development. There is increasing evidence that adverse prenatal conditions result in fetal epigenetic imprinting with long-term consequences on sexspecific immune system development. For example, prenatal micronutrition as well as maternal vitamin supplementation can have sex-differential effects on immunity in offspring, mostly on an epigenetic level $(156,157)$. Neurodevelopmental defects and neuroimmunological impairments observed in offspring born to mothers who experienced gestational stress have been shown to be sex-specific (158-160). Some studies suggest that female fetuses are more resistant to intra-uterine stress $(161,162)$. Postnatally, the protective effect of breast feeding seems to be stronger in female neonates compared to males, resulting in increased protection against respiratory infections in female neonates (163). Sex steroid concentrations do not differ between the sexes in infancy, except during the first three months of life, when male neonates express increased testosterone concentrations, followed by a gradual decline (164). Although most studies on maternal 
immune activation and in utero priming of the offspring are focused on neurodevelopment, there is increasing evidence from animal models that prenatal stress also affects the offspring's immune-development in a sex-specific manner (165-167). Maternal immune activation in mice can disrupt the offspring's immunological homeostasis with increased Th1 immunity in male offspring, particularly (165). Offspring born to dams that receive immunological stimulation (e.g., injection with lipopolysaccharide) also present with more activated, proinflammatory macrophages through adulthood (166); these studies, however, neglect consideration of the sex of the offspring.

The long-term effects of SARS-CoV-2 infection on offspring exposed to infection during pregnancy are currently not know. While most studies do not report vertical transmission of SARS-CoV-2, other mechanisms such as maternal and fetal hypoxia, disruption of placental integrity, or maternal immune activation and trans-placental transfer of pro-inflammatory cytokines must be assessed to understand possible implications on the offspring's development and underlying sex-specific effects (168). Transfer of antibodies across the placenta might be an important contributor to sex-specific pathogenesis during SARS-CoV-2. While it has been shown that the neonatal Fcreceptor is crucial for antibody-transfer across the placenta, the placental interferon response affects Fc-receptor expression (169). Infection with SARS-CoV-2 during pregnancy results in sex differences in placental expression of interferon-stimulated genes and the Fc-receptor, with an upregulation in male fetuses, resulting in male-biased impaired transplacental antibodytransfer (169). Another study involving over 88.000 infants born in Sweden during the COVID-19 pandemic found a significant association between maternal SARS-CoV-2 infection and the absolute risk of respiratory and other neonatal disorders, but no increase in neonatal mortality. Unfortunately, neonatal outcomes were not sex disaggregated (170). Whereas several studies report that neonates born to SARS-CoV-2 positive women are more likely to need neonatal ICU admission, these data are generally not stratified for the offspring's sex (171).

\section{CONCLUSIONS AND FUTURE DIRECTIONS}

There are sex differences in immunity to viruses that result in differential outcomes and pathogenesis of viral infections. Future

\section{REFERENCES}

1. Bischof E, Wolfe J, Klein SL. Clinical Trials for COVID-19 Should Include Sex as a Variable. J Clin Invest (2020) 130:3350-2. doi: 10.1172/ JCI139306

2. Peckham H, de Gruijter NM, Raine C, Radziszewska A, Ciurtin C, Wedderburn LR, et al. Male Sex Identified by Global COVID-19 MetaAnalysis as a Risk Factor for Death and ITU Admission. Nat Commun (2020) 11:6317. doi: 10.1038/s41467-020-19741-6

3. Marina S, Piemonti L. Gender and Age Effects on the Rates of Infection and Deaths in Individuals With Confirmed SARS-CoV-2 Infection in Six European Countries (2020). Available at: https://papers.ssrn.com/abstract=3576790. studies should not only evaluate how sex differences in immunity alter the pathogenesis of viral infection and responses to vaccines, but consider the other pathways that may be differentially regulated between the sexes. For example, in the context of COVID-19, females show greater expression of type I IFN signaling and other innate immune responses and $\mathrm{T}$ cellassociated genes while cells from males exhibit greater expression of inflammatory genes (172). Sex differences in immunity are directly affected by sex chromosome complement through the differential activity of X-linked genes as well as ChrY gene polymorphisms that are regulated by escape from $\mathrm{X}$ inactivation and epigenetic mechanisms, respectively. The concentrations of sex steroids change over the life course, and directly affect immunity to viruses through the sex differential expression of sex steroid receptors in immune cells. Knowledge of sex differences in immunity to viruses and vaccines should inform greater consideration of sex disaggregation of data rather than statistical controlling for sex in clinical studies (173). Reporting of the sex of animals and primary cells as well as comparing immunological responses between the sexes in preclinical research is necessary (174). The COVID-19 pandemic has raised awareness about the significance of sex as a biological variable and how sex intersects with other variables, including age and race $(45,89,91,175)$. Intersectional approaches are going to be necessary to better understanding outcomes of viral infections as well as treatments for infection, with knowledge that both will likely differ between the sexes.

\section{AUTHOR CONTRIBUTIONS}

HJ outlined and wrote the first draft of the manuscript. SK edited and finalized the manuscript. SK conceived of the figure and HJ produced the figure. All authors contributed to the article and approved the submitted version.

\section{FUNDING}

The writing of this review was made possible through funds from the NIH/NIA funded Johns Hopkins Specialized Center of Research Excellence (SCORE) in sex and age differences in immunity to influenza (SADII; U54AG062333).The funders had no role in the writing or content of this review.

4. Chen N, Zhou M, Dong X, Qu J, Gong F, Han Y, et al. Epidemiological and Clinical Characteristics of 99 Cases of 2019 Novel Coronavirus Pneumonia in Wuhan, China: A Descriptive Study. Lancet (2020) 395:507-13. doi: 10.1016/S0140-6736(20)30211-7

5. Guan W, Ni Z, Hu Y, Liang W, Ou C, He J, et al. Clinical Characteristics of Coronavirus Disease 2019 in China. N Engl J Med (2020) 382(18):1708-20. doi: 10.1056/NEJMoa2002032

6. Pan A, Liu L, Wang C, Guo H, Hao X, Wang Q, et al. Association of Public Health Interventions With the Epidemiology of the COVID-19 Outbreak in Wuhan, China. JAMA (2020) 323:1-9. doi: 10.1001/jama.2020.6130

7. Scully EP, Haverfield J, Ursin RL, Tannenbaum C, Klein SL. Considering How Biological Sex Impacts Immune Responses and COVID-19 
Outcomes. Nat Rev Immunol (2020) 20:442-7. doi: 10.1038/s41577-0200348-8

8. Islam N, Shkolnikov VM, Acosta RJ, Klimkin I, Kawachi I, Irizarry RA, et al. Excess Deaths Associated With Covid-19 Pandemic in 2020: Age and Sex Disaggregated Time Series Analysis in 29 High Income Countries. BMJ (2021) 373:n1137. doi: 10.1136/bmj.n1137

9. The COVID-19 Sex-Disaggregated Data Tracker | Global Health 50/50. Available at: https://globalhealth5050.org/the-sex-gender-and-covid-19project/the-data-tracker/.

10. Bernin H, Lotter H. Sex Bias in the Outcome of Human Tropical Infectious Diseases: Influence of Steroid Hormones. J Infect Dis (2014) 209:S107-13. doi: 10.1093/infdis/jit610

11. vom Steeg LG, Klein SL. SeXX Matters in Infectious Disease Pathogenesis. PloS Pathog (2016) 12. doi: 10.1371/journal.ppat.1005374

12. Klein SL. Sex Influences Immune Responses to Viruses, and Efficacy of Prophylaxis and Treatments for Viral Diseases. BioEssays (2012) 34:1050-9. doi: 10.1002/bies.201200099

13. Guha-Sapir D, Schimmer B. Dengue Fever: New Paradigms for a Changing Epidemiology. Emerg Themes Epidemiol (2005) 2:1. doi: 10.1186/1742-7622-2-1

14. Klein SL, Marks MA, Li W, Glass GE, Fang L-Q, Ma J-Q, et al. Sex Differences in the Incidence and Case Fatality Rates From Hemorrhagic Fever With Renal Syndrome in China, 2004-2008. Clin Infect Dis (2011) 52:1414-21. doi: 10.1093/cid/cir232

15. Tsay P-K, Tai D-I, Chen Y-M, Yu C-P, Wan S-Y, Shen Y-J, et al. Impact of Gender, Viral Transmission and Aging in the Prevalence of Hepatitis B Surface Antigen. Chang Gung Med J (2009) 32:155-64.

16. Burguete-García AI, Conde-González CJ, Jiménez-Méndez R, Juárez-Díaz Y, Meda-Monzón E, Torres-Poveda K, et al. Hepatitis C Seroprevalence and Correlation Between Viral Load and Viral Genotype Among Primary Care Clients in Mexico. Salud Publica Mex (2011) 53(Suppl 1):S7-12.

17. Balogun MA, Vyse AJ, Hesketh LM, Kafatos G, Parry JV, Ramsay ME. Estimating Hepatitis C Infection Acquired in England, 1986-2000. Epidemiol Infect (2009) 137:1249-54. doi: 10.1017/S0950268809002143

18. Murphy G, Pfeiffer R, Camargo MC, Rabkin CS. Meta-Analysis Shows That Prevalence of Epstein-Barr Virus-Positive Gastric Cancer Differs Based on Sex and Anatomic Location. Gastroenterology (2009) 137:824-33. doi: 10.1053/j.gastro.2009.05.001

19. Wang S-H, Yeh S-H, Lin W-H, Wang H-Y, Chen D-S, Chen P-J. Identification of Androgen Response Elements in the Enhancer I of Hepatitis B Virus: A Mechanism for Sex Disparity in Chronic Hepatitis B. Hepatology (2009) 50:1392-402. doi: 10.1002/hep.23163

20. Yu MW, Cheng SW, Lin MW, Yang SY, Liaw YF, Chang HC, et al. Androgen-Receptor Gene CAG Repeats, Plasma Testosterone Levels, and Risk of Hepatitis B-Related Hepatocellular Carcinoma. J Natl Cancer Inst (2000) 92:2023-8. doi: 10.1093/jnci/92.24.2023

21. Jean CM, Honarmand S, Louie JK, Glaser CA. Risk Factors for West Nile Virus Neuroinvasive Disease, California, 2005. Emerg Infect Dis (2007) 13:1918-20. doi: 10.3201/eid1312.061265

22. Villacres MC, Longmate J, Auge C, Diamond DJ. Predominant Type 1 CMV-Specific Memory T-Helper Response in Humans: Evidence for Gender Differences in Cytokine Secretion. Hum Immunol (2004) 65:47685. doi: 10.1016/j.humimm.2004.02.021

23. Wald A. Herpes Simplex Virus Type 2 Transmission: Risk Factors and Virus Shedding. Herpes (2004) 11(Suppl 3):3, 130A-137A.

24. Fleming DT, McQuillan GM, Johnson RE, Nahmias AJ, Aral SO, Lee FK, et al. Herpes Simplex Virus Type 2 in the United States, 1976 to 1994. N Engl J Med (1997) 337:1105-11. doi: 10.1056/NEJM199710163371601

25. Eshima N, Iwata O, Iwata S, Tabata M, Higuchi Y, Matsuishi T, et al. Age and Gender Specific Prevalence of HTLV-1. J Clin Virol (2009) 45:135-8. doi: $10.1016 /$ j.jcv.2009.03.012

26. Griesbeck M, Altfeld M. Sex Differences in the Manifestations of HIV-1 Infection. In: Klein SL, Roberts CW, editors. Sex and Gender Differences in Infection and Treatments for Infectious Diseases. Cham: Springer International Publishing (2015). p. 103-81. doi: 10.1007/978-3-319-16438-0_5

27. World Health Organization. Sex, Gender and Influenza. Geneva:World Health Organization (2010).

28. Zarychanski R, Stuart TL, Kumar A, Doucette S, Elliott L, Kettner J, et al. Correlates of Severe Disease in Patients With 2009 Pandemic Influenza
(H1N1) Virus Infection. CMAJ (2010) 182:257-64. doi: 10.1503/ cmaj.091884

29. Garenne M. Sex Differences in Measles Mortality: A World Review. Int J Epidemiol (1994) 23:632-42. doi: 10.1093/ije/23.3.632

30. Karlberg J, Chong DSY, Lai WYY. Do Men Have a Higher Case Fatality Rate of Severe Acute Respiratory Syndrome Than Women do? Am J Epidemiol (2004) 159:229-31. doi: 10.1093/aje/kwh056

31. Leong H-N, Earnest A, Lim H-H, Chin C-F, Tan CSH, Puhaindran ME, et al. SARS in Singapore-predictors of Disease Severity. Ann Acad Med Singap (2006) 35:326-31.

32. Alghamdi IG, Hussain II, Almalki SS, Alghamdi MS, Alghamdi MM, ElSheemy MA. The Pattern of Middle East Respiratory Syndrome Coronavirus in Saudi Arabia: A Descriptive Epidemiological Analysis of Data From the Saudi Ministry of Health. Int J Gen Med (2014) 7:417-23. doi: 10.2147/IJGM.S67061

33. Jansen A, Chiew M, Konings F, Lee C-K, Ailan L. Sex Matters - A Preliminary Analysis of Middle East Respiratory Syndrome in the Republic of Korea, 2015. Western Pac Surveill Response J (2015) 6:68-71. doi: 10.5365/wpsar.2015.6.3.002

34. Klein SL, Flanagan KL. Sex Differences in Immune Responses. Nat Rev Immunol (2016) 16:626-38. doi: 10.1038/nri.2016.90

35. Angum F, Khan T, Kaler J, Siddiqui L, Hussain A. The Prevalence of Autoimmune Disorders in Women: A Narrative Review. Cureus 12(5): e8094. doi: 10.7759/cureus.8094.

36. Fairweather D, Rose NR. Women and Autoimmune Diseases1. Emerg Infect Dis (2004) 10:2005-11. doi: 10.3201/eid1011.040367

37. Markle JGM, Frank DN, Mortin-Toth S, Robertson CE, Feazel LM, Rolle-Kampczyk U, et al. Sex Differences in the Gut Microbiome Drive Hormone-Dependent Regulation of Autoimmunity. Science (2013) 339:1084-8. doi: 10.1126/science.1233521

38. Foxman B. The Epidemiology of Urinary Tract Infection. Nat Rev Urol (2010) 7:653-60. doi: 10.1038/nrurol.2010.190

39. Sierpiński R, Pinkas J, Jankowski M, Zgliczyński WS, Wierzba W, Gujski M, et al. Sex Differences in the Frequency of Gastrointestinal Symptoms and Olfactory or Taste Disorders in 1942 Nonhospitalized Patients With Coronavirus Disease 2019 (COVID-19). Pol Arch Intern Med (2020) 130:501-5. doi: 10.20452/pamw.15414

40. Falagas ME, Mourtzoukou EG, Vardakas KZ. Sex Differences in the Incidence and Severity of Respiratory Tract Infections. Respir Med (2007) 101:1845-63. doi: 10.1016/j.rmed.2007.04.011

41. Andersen LK, Davis MDP. Sex Differences in the Incidence of Skin and SkinRelated Diseases in Olmsted County, Minnesota, United States, and a Comparison With Other Rates Published Worldwide. Int J Dermatol (2016) 55:939-55. doi: 10.1111/ijd.13285

42. Dao H, Kazin RA. Gender Differences in Skin: A Review of the Literature. Gender Med (2007) 4:308-28. doi: 10.1016/S1550-8579(07)80061-1

43. Houdeau E. Chapter 8 - Sex Differences in Gastrointestinal Physiology and Diseases: From Endogenous Sex Hormones to Environmental Endocrine Disruptor Agents. In: GN Neigh and MM Mitzelfelt, editors. Sex Differences in Physiology. Cambridge: Academic Press (2016). p. 125-43. doi: 10.1016/ B978-0-12-802388-4.00008-2

44. Klein SL, Morgan R. The Impact of Sex and Gender on Immunotherapy Outcomes. Biol Sex Differ (2020) 11:24. doi: 10.1186/s13293-020-00301-y

45. Klein SL, Pekosz A, Park H-S, Ursin RL, Shapiro JR, Benner SE, et al. Sex, Age, and Hospitalization Drive Antibody Responses in a COVID-19 Convalescent Plasma Donor Population. J Clin Invest (2020) 130:6141-50. doi: $10.1172 / \mathrm{JCI} 142004$

46. Aaby P, Benn CS, Flanagan KL, Klein SL, Kollmann TR, Lynn DJ, et al. The non-Specific and Sex-Differential Effects of Vaccines. Nat Rev Immunol (2020) 20(8):464-70. doi: 10.1038/s41577-020-0338-x

47. Fink AL, Klein SL. The Evolution of Greater Humoral Immunity in Females Than Males: Implications for Vaccine Efficacy. Curr Opin Physiol (2018) 6:16-20. doi: 10.1016/j.cophys.2018.03.010

48. Fischinger S, Boudreau CM, Butler AL, Streeck H, Alter G. Sex Differences in Vaccine-Induced Humoral Immunity. Semin Immunopathol (2019) 41:23949. doi: 10.1007/s00281-018-0726-5

49. Lipsky BA. Urinary Tract Infections in Men. Epidemiology, Pathophysiology, Diagnosis, and Treatment. Ann Intern Med (1989) 110:138-50. doi: 10.7326/0003-4819-110-2-138 
50. Phillips Ii G, Xu J, Ruprecht MM, Costa D, Felt D, Wang X, et al. Associations With COVID-19 Symptoms, Prevention Interest, and Testing Among Sexual and Gender Minority Adults in a Diverse National Sample. LGBT Health (2021) 8:322-9. doi: 10.1089/lgbt.2021.0002

51. van der Miesen AIR, Raaijmakers D, van de Grift TC. "You Have to Wait a Little Longer": Transgender (Mental) Health at Risk as a Consequence of Deferring Gender-Affirming Treatments During COVID-19. Arch Sex Behav (2020) 49(5):1395-9. doi: 10.1007/s10508-020-01754-3

52. Wozniak RJ, Nixon DF, Marston JL. Involvement of Cisgender and Transgender Individuals in Studies on the Impact of Hormonal Therapy on COVID-19. AIDS Patient Care STDS (2020) 34:367-8. doi: 10.1089/ apc. 2020.0118

53. SL Klein and CW RobertsSex and Gender Differences in Infection and Treatments for Infectious Diseases. Springer Cham; Heidelberg, New York; Dordrecht, London: Springer International Publishing (2015). doi: 10.1007/ 978-3-319-16438-0

54. Miller LR, Marks C, Becker JB, Hurn PD, Chen W-J, Woodruff T, et al. Considering Sex as a Biological Variable in Preclinical Research. FASEB J (2017) 31:29-34. doi: 10.1096/fj.201600781r

55. de Heredia FP, Gómez-Martínez S, Marcos A. Obesity, Inflammation and the Immune System. Proc Nutr Soc (2012) 71:332-8. doi: 10.1017/ S0029665112000092

56. Milner JJ, Beck MA. The Impact of Obesity on the Immune Response to Infection. Proc Nutr Soc (2012) 71:298-306. doi: 10.1017/S0029665112000158

57. Castelo-Branco C, Soveral I. The Immune System and Aging: A Review. Gynecol Endocrinol (2014) 30:16-22. doi: 10.3109/09513590.2013.852531

58. Giefing-Kröll C, Berger P, Lepperdinger G, Grubeck-Loebenstein B. How Sex and Age Affect Immune Responses, Susceptibility to Infections, and Response to Vaccination. Aging Cell (2015) 14:309-21. doi: 10.1111/ acel.12326

59. Aspinall R. Longevity and the Immune Response. Biogerontology (2000) 1:273-8. doi: 10.1023/A:1010046532657

60. Hirokawa K, Utsuyama M, Hayashi Y, Kitagawa M, Makinodan T, Fulop T. Slower Immune System Aging in Women Versus Men in the Japanese Population. Immun Ageing (2013) 10:19. doi: 10.1186/1742-4933-10-19

61. Shapiro JR, Klein SL, Morgan R. COVID-19: Use Intersectional Analyses to Close Gaps in Outcomes and Vaccination. Nature (2021) 591:202-2. doi: 10.1038/d41586-021-00577-Z

62. Xia H-J, Zhang G-H, Wang R-R, Zheng Y-T. The Influence of Age and Sex on the Cell Counts of Peripheral Blood Leukocyte Subpopulations in Chinese Rhesus Macaques. Cell Mol Immunol (2009) 6:433-40. doi: 10.1038/cmi.2009.55

63. Hewagama A, Patel D, Yarlagadda S, Strickland FM, Richardson BC. Stronger Inflammatory/Cytotoxic T-Cell Response in Women Identified by Microarray Analysis. Genes Immun (2009) 10:509-16. doi: 10.1038/ gene.2009.12

64. Boissier J, Chlichlia K, Digon Y, Ruppel A, Moné H. Preliminary Study on Sex-Related Inflammatory Reactions in Mice Infected With Schistosoma Mansoni. Parasitol Res (2003) 91:144-50. doi: 10.1007/s00436-003-0943-1

65. Ter Horst R, Jaeger M, Smeekens SP, Oosting M, Swertz MA, Li Y, et al. Host and Environmental Factors Influencing Individual Human Cytokine Responses. Cell (2016) 167:1111-1124.e13. doi: 10.1016/j.cell.2016.10.018

66. Channappanavar R, Fett C, Mack M, Ten Eyck PP, Meyerholz DK, Perlman S. Sex-Based Differences in Susceptibility to Severe Acute Respiratory Syndrome Coronavirus Infection. J Immunol (2017) 198:4046-53. doi: 10.4049/jimmunol.1601896

67. Steeg LG, Dhakal S, Woldetsadik YA, Park H-S, Mulka KR, Reilly EC, et al. Androgen Receptor Signaling in the Lungs Mitigates Inflammation and Improves the Outcome of Influenza in Mice. PloS Pathog (2020) 16: e1008506. doi: 10.1371/journal.ppat.1008506

68. Szaniawski MA, Spivak AM, Bosque A, Planelles V. Sex Influences SAMHD1 Activity and Susceptibility to Human Immunodeficiency Virus1 in Primary Human Macrophages. J Infect Dis (2019) 219:777-85. doi: 10.1093/infdis/jiy583

69. Hagen SH, Henseling F, Hennesen J, Savel H, Delahaye S, Richert L, et al. Heterogeneous Escape From X Chromosome Inactivation Results in Sex Differences in Type I IFN Responses at the Single Human pDC Level. Cell Rep (2020) 33:108485. doi: 10.1016/j.celrep.2020.108485
70. Meier A, Chang JJ, Chan ES, Pollard RB, Sidhu HK, Kulkarni S, et al. Sex Differences in the Toll-Like Receptor-Mediated Response of Plasmacytoid Dendritic Cells to HIV-1. Nat Med (2009) 15:955-9. doi: 10.1038/nm.2004

71. Chang JJ, Woods M, Lindsay RJ, Doyle EH, Griesbeck M, Chan ES, et al. Higher Expression of Several Interferon-Stimulated Genes in HIV-1Infected Females After Adjusting for the Level of Viral Replication. J Infect Dis (2013) 208:830-8. doi: 10.1093/infdis/jit262

72. Griesbeck M, Ziegler S, Laffont S, Smith N, Chauveau L, Tomezsko P, et al. Sex Differences in Plasmacytoid Dendritic Cell Levels of IRF5 Drive Higher IFN- $\alpha$ Production in Women. J Immunol (2015) 195:5327-36. doi: 10.4049/ jimmunol.1501684

73. Amadori A, Zamarchi R, De Silvestro G, Forza G, Cavatton G, Danieli GA, et al. Genetic Control of the CD4/CD8 T-Cell Ratio in Humans. Nat Med (1995) 1:1279-83. doi: 10.1038/nm1295-1279

74. Abdullah M, Chai P-S, Chong M-Y, Tohit ERM, Ramasamy R, Pei CP, et al. Gender Effect on In Vitro Lymphocyte Subset Levels of Healthy Individuals. Cell Immunol (2012) 272:214-9. doi: 10.1016/j.cellimm.2011.10.009

75. Lee BW, Yap HK, Chew FT, Quah TC, Prabhakaran K, Chan GS, et al. Ageand Sex-Related Changes in Lymphocyte Subpopulations of Healthy Asian Subjects: From Birth to Adulthood. Cytometry (1996) 26:8-15. doi: 10.1002/ (SICI)1097-0320(19960315)26:1<8::AID-CYTO2>3.0.CO;2-E

76. Lisse IM, Aaby P, Whittle H, Jensen H, Engelmann M, Christensen LB. TLymphocyte Subsets in West African Children: Impact of Age, Sex, and Season. J Pediatr (1997) 130:77-85. doi: 10.1016/S0022-3476(97)70313-5

77. Uppal SS, Verma S, Dhot PS. Normal Values of CD4 and CD8 Lymphocyte Subsets in Healthy Indian Adults and the Effects of Sex, Age, Ethnicity, and Smoking. Cytometry B Clin Cytom (2003) 52:32-6. doi: 10.1002/ cyto.b.10011

78. Teixeira D, Longo-Maugeri IM, Santos JLF, Duarte YAO, Lebrão ML, Bueno V. Evaluation of Lymphocyte Levels in a Random Sample of 218 Elderly Individuals From São Paulo City. Rev Bras Hematol Hemoter (2011) 33:36771. doi: 10.5581/1516-8484.20110100

79. Sankaran-Walters S, Macal M, Grishina I, Nagy L, Goulart L, Coolidge K, et al. Sex Differences Matter in the Gut: Effect on Mucosal Immune Activation and Inflammation. Biol Sex Differ (2013) 4:10. doi: 10.1186/ 2042-6410-4-10

80. Weinstein Y, Ran S, Segal S. Sex-Associated Differences in the Regulation of Immune Responses Controlled by the MHC of the Mouse. J Immunol (1984) 132:656-61.

81. Roberts CW, Walker W, Alexander J. Sex-Associated Hormones and Immunity to Protozoan Parasites. Clin Microbiol Rev (2001) 14:476-88. doi: 10.1128/CMR.14.3.476-488.2001

82. Afshan G, Afzal N, Qureshi S. CD4+CD25(hi) Regulatory T Cells in Healthy Males and Females Mediate Gender Difference in the Prevalence of Autoimmune Diseases. Clin Lab (2012) 58:567-71.

83. Klein SL, Jedlicka A, Pekosz A. The Xs and Y of Immune Responses to Viral Vaccines. Lancet Infect Dis (2010) 10:338-49. doi: 10.1016/S1473-3099(10) 70049-9

84. Furman D, Hejblum BP, Simon N, Jojic V, Dekker CL, Thiébaut R, et al. Systems Analysis of Sex Differences Reveals an Immunosuppressive Role for Testosterone in the Response to Influenza Vaccination. PNAS (2014) 111:869-74. doi: 10.1073/pnas.1321060111

85. Butterworth M, Mcclellan B, Aklansmith M. Influence of Sex on Immunoglobulin Levels. Nature (1967) 214:1224-5. doi: 10.1038/2141224a0

86. Purtilo DT, Sullivan JL. Immunological Bases for Superior Survival of Females. Am J Dis Children (1979) 133:1251-3. doi: 10.1001/archpedi. 1979.02130120043008

87. Xu K, Chen Y, Yuan J, Yi P, Ding C, Wu W, et al. Factors Associated With Prolonged Viral RNA Shedding in Patients With Coronavirus Disease 2019 (COVID-19). Clin Infect Dis (2020) 71:799-806. doi: 10.1093/cid/ciaa351

88. Zheng S, Fan J, Yu F, Feng B, Lou B, Zou Q, et al. Viral Load Dynamics and Disease Severity in Patients Infected With SARS-CoV-2 in Zhejiang Province, China, January-March 2020: Retrospective Cohort Study. BMJ (2020) 369:m1443. doi: 10.1136/bmj.m1443

89. Del Valle DM, Kim-Schulze S, Huang H-H, Beckmann ND, Nirenberg S, Wang B, et al. An Inflammatory Cytokine Signature Predicts COVID-19 Severity and Survival. Nat Med (2020) 26:1636-43. doi: 10.1038/s41591-0201051-9 
90. Scully EP, Schumock G, Fu M, Massaccesi G, Muschelli J, Betz J, et al. Sex and Gender Differences in COVID Testing, Hospital Admission, Presentation, and Drivers of Severe Outcomes in the DC/Maryland Region. medRxiv (2021). doi: 10.1101/2021.04.05.21253827

91. Takahashi T, Wong P, Ellingson M, Lucas C, Klein J, Israelow B, et al. Sex Differences in Immune Responses to SARS-CoV-2 That Underlie Disease Outcomes. medRxiv (2020) 2020:6.06.20123414. doi: 10.1101/2020. 06.06.20123414

92. Zhao G, Xu Y, Li J, Cui X, Tan X, Zhang H, et al. Sex Differences in Immune Responses to SARS-CoV-2 in Patients With COVID-19. Biosci Rep (2021) 41(1):BSR20202074. doi: 10.1042/BSR20202074.

93. Ursin RL, Shapiro JR, Klein SL. Sex-Biased Immune Responses Following SARS-CoV-2 Infection. Trends Microbiol (2020) 28:952-4. doi: 10.1016/ j.tim.2020.10.002

94. Grzelak L, Velay A, Madec Y, Gallais F, Staropoli I, Schmidt-Mutter C, et al. Sex Differences in the Evolution of Neutralizing Antibodies to SARS-CoV-2. J Infect Dis (2021) jiab127. doi: 10.1093/infdis/jiab127

95. CDC COVID-19 Vaccine Breakthrough Case Investigations Team, Birhane M, Bressler S, Chang G, Clark T, et al. COVID-19 Vaccine Breakthrough Infections Reported to CDC - United States, January 1-April 30, 2021. MMWR Morb. Mortal. Wkly. Rep (2021) 70:792-3. doi: 10.15585/ mmwr.mm7021e3

96. Demonbreun AR, Sancilio A, Velez ME, Ryan DT, Pesce L, Saber R, et al. COVID-19 mRNA Vaccination Generates Greater Immunoglobulin G Levels in Women Compared to Men. J Infect Dis (2021) jiab314. doi: 10.1093/infdis/jiab314

97. Shepherd R, Cheung AS, Pang K, Saffery R, Novakovic B. Sexual Dimorphism in Innate Immunity: The Role of Sex Hormones and Epigenetics. Front Immunol (2021) 11:604000. doi: 10.3389/fimmu. 2020.604000 .

98. Taneja V. Sex Hormones Determine Immune Response. Front Immunol (2018) 9:1931. doi: 10.3389/fimmu.2018.01931

99. Chan WK, Klock G, Bernard HU. Progesterone and Glucocorticoid Response Elements Occur in the Long Control Regions of Several Human Papillomaviruses Involved in Anogenital Neoplasia. J Virol (1989) 63:32619. doi: $10.1128 /$ jvi.63.8.3261-3269.1989

100. SL Klein and CW RobertsSex Hormones and Immunity to Infection. Springer Berlin Heidelberg: Springer-Verlag (2010). doi: 10.1007/978-3-642-02155-8

101. Fox HS, Bond BL, Parslow TG. Estrogen Regulates the IFN-Gamma Promoter. J Immunol (1991) 146:4362-7.

102. Phiel KL, Henderson RA, Adelman SJ, Elloso MM. Differential Estrogen Receptor Gene Expression in Human Peripheral Blood Mononuclear Cell Populations. Immunol Lett (2005) 97:107-13. doi: 10.1016/ j.imlet.2004.10.007

103. Dai R, McReynolds S, LeRoith T, Heid B, Liang Z, Ahmed SA. Sex Differences in the Expression of Lupus-Associated miRNAs in Splenocytes From Lupus-Prone NZB/WF1 Mice. Biol Sex Differ (2013) 4:19. doi: 10.1186/ 2042-6410-4-19

104. Kovats S. Estrogen Receptors Regulate Innate Immune Cells and Signaling Pathways. Cell Immunol (2015) 294:63-9. doi: 10.1016/j.cellimm.2015.01.018

105. Robinson DP, Lorenzo ME, Jian W, Klein SL. Elevated 17ß-Estradiol Protects Females From Influenza A Virus Pathogenesis by Suppressing Inflammatory Responses. PloS Pathog (2011) 7:e1002149. doi: 10.1371/ journal.ppat.1002149

106. Bouman A, Heineman MJ, Faas MM. Sex Hormones and the Immune Response in Humans. Hum Reprod Update (2005) 11:411-23. doi: 10.1093/ humupd/dmi008

107. Straub RH. The Complex Role of Estrogens in Inflammation. Endocr Rev (2007) 28:521-74. doi: 10.1210/er.2007-0001

108. Lü FX, Abel K, Ma Z, Rourke T, Lu D, Torten J, et al. The Strength of B Cell Immunity in Female Rhesus Macaques Is Controlled by CD8+ T Cells Under the Influence of Ovarian Steroid Hormones. Clin Exp Immunol (2002) 128:10-20. doi: 10.1046/j.1365-2249.2002.01780.x

109. Nakaya M, Tachibana H, Yamada K. Effect of Estrogens on the InterferonGamma Producing Cell Population of Mouse Splenocytes. Biosci Biotechnol Biochem (2006) 70:47-53. doi: 10.1271/bbb.70.47

110. Hao S, Zhao J, Zhou J, Zhao S, Hu Y, Hou Y. Modulation of 17beta-Estradiol on the Number and Cytotoxicity of NK Cells In Vivo Related to MCM and
Activating Receptors. Int Immunopharmacol (2007) 7:1765-75. doi: 10.1016/ j.intimp.2007.09.017

111. Paharkova-Vatchkova V, Maldonado R, Kovats S. Estrogen Preferentially Promotes the Differentiation of CD11c+ CD11b(intermediate) Dendritic Cells From Bone Marrow Precursors. J Immunol (2004) 172:1426-36. doi: 10.4049/jimmunol.172.3.1426

112. Bengtsson AK, Ryan EJ, Giordano D, Magaletti DM, Clark EA. 17betaEstradiol (E2) Modulates Cytokine and Chemokine Expression in Human Monocyte-Derived Dendritic Cells. Blood (2004) 104:1404-10. doi: 10.1182/ blood-2003-10-3380

113. Polanczyk MJ, Carson BD, Subramanian S, Afentoulis M, Vandenbark AA, Ziegler SF, et al. Cutting Edge: Estrogen Drives Expansion of the CD4+CD25+ Regulatory T Cell Compartment. J Immunol (2004) 173:2227-30. doi: 10.4049/jimmunol.173.4.2227

114. Pauklin S, Sernández IV, Bachmann G, Ramiro AR, Petersen-Mahrt SK. Estrogen Directly Activates AID Transcription and Function. J Exp Med (2009) 206:99-111. doi: 10.1084/jem.20080521

115. Potluri T, Fink AL, Sylvia KE, Dhakal S, Vermillion MS, Vom Steeg L, et al. Age-Associated Changes in the Impact of Sex Steroids on Influenza Vaccine Responses in Males and Females. NPJ Vaccines (2019) 4:1-12. doi: 10.1038/ s41541-019-0124-6

116. Piccinni MP, Giudizi MG, Biagiotti R, Beloni L, Giannarini L, Sampognaro S, et al. Progesterone Favors the Development of Human T Helper Cells Producing Th2-Type Cytokines and Promotes Both IL-4 Production and Membrane CD30 Expression in Established Th1 Cell Clones. J Immunol (1995) 155:128-33.

117. Lee JH, Ulrich B, Cho J, Park J, Kim CH. Progesterone Promotes Differentiation of Human Cord Blood Fetal T Cells Into T Regulatory Cells But Suppresses Their Differentiation Into Th17 Cells. J Immunol (2011) 187:1778-87. doi: 10.4049/jimmunol.1003919

118. Teilmann SC, Clement CA, Thorup J, Byskov AG, Christensen ST. Expression and Localization of the Progesterone Receptor in Mouse and Human Reproductive Organs. J Endocrinol (2006) 191:525-35. doi: 10.1677/joe.1.06565

119. Butts CL, Shukair SA, Duncan KM, Bowers E, Horn C, Belyavskaya E, et al. Progesterone Inhibits Mature Rat Dendritic Cells in a Receptor-Mediated Fashion. Int Immunol (2007) 19:287-96. doi: 10.1093/intimm/dxl145

120. Hall OJ, Limjunyawong N, Vermillion MS, Robinson DP, Wohlgemuth N, Pekosz A, et al. Progesterone-Based Therapy Protects Against Influenza by Promoting Lung Repair and Recovery in Females. PloS Pathog (2016) 12: e1005840. doi: 10.1371/journal.ppat.1005840

121. Hall OJ, Nachbagauer R, Vermillion MS, Fink AL, Phuong V, Krammer F, et al. Progesterone-Based Contraceptives Reduce Adaptive Immune Responses and Protection Against Sequential Influenza A Virus Infections. J Virol (2017) 91(8):e02160-16. doi: 10.1128/JVI.02160-16

122. McKay LI, Cidlowski JA. Molecular Control of Immune/Inflammatory Responses: Interactions Between Nuclear Factor-Kappa B and Steroid Receptor-Signaling Pathways. Endocr Rev (1999) 20:435-59. doi: 10.1210/ edrv.20.4.0375

123. Hou J, Zheng WF. Effect of Sex Hormones on NK and ADCC Activity of Mice. Int J Immunopharmacol (1988) 10:15-22. doi: 10.1016/0192-0561(88) 90145-2

124. D’agostino P, Milano S, Barbera C, Bella GD, Rosa ML, Ferlazzo V, et al. Sex Hormones Modulate Inflammatory Mediators Produced by Macrophagesa. Ann New York Acad Sci (1999) 876:426-9. doi: 10.1111/j.1749-6632.1999. tb07667.x

125. Liva SM, Voskuhl RR. Testosterone Acts Directly on CD4+ T Lymphocytes to Increase IL-10 Production. J Immunol (2001) 167:2060-7. doi: 10.4049/ jimmunol.167.4.2060

126. Torcia MG, Nencioni L, Clemente AM, Civitelli L, Celestino I, Limongi D, et al. Sex Differences in the Response to Viral Infections: TLR8 and TLR9 Ligand Stimulation Induce Higher IL10 Production in Males. PloS One (2012) 7:e39853. doi: 10.1371/journal.pone.0039853

127. Vom Steeg LG, Vermillion MS, Hall OJ, Alam O, McFarland R, Chen H, et al. Age and Testosterone Mediate Influenza Pathogenesis in Male Mice. Am J Physiol Lung Cell Mol Physiol (2016) 311:L1234-44. doi: 10.1152/ajplung. 00352.2016

128. Smith-Bouvier DL, Divekar AA, Sasidhar M, Du S, Tiwari-Woodruff SK, King JK, et al. A Role for Sex Chromosome Complement in the Female Bias 
in Autoimmune Disease. J Exp Med (2008) 205:1099-108. doi: 10.1084/ jem. 20070850

129. Burgoyne PS, Thornhill AR, Boudrean SK, Darling SM, Bishop CE, Evans EP. The Genetic Basis of XX-XY Differences Present Before Gonadal Sex Differentiation in the Mouse. Philos Trans R Soc Lond B Biol Sci (1995) 350:253-60, discussion 260-1. doi: 10.1098/rstb.1995.0159

130. Fish EN. The X-Files in Immunity: Sex-Based Differences Predispose Immune Responses. Nat Rev Immunol (2008) 8:737-44. doi: 10.1038/ nri2394

131. Migeon BR. The Role of X Inactivation and Cellular Mosaicism in Women's Health and Sex-Specific Diseases. JAMA (2006) 295:1428-33. doi: 10.1001/ jama.295.12.1428

132. Morris JA, Harrison LM. Hypothesis: Increased Male Mortality Caused by Infection Is Due to a Decrease in Heterozygous Loci as a Result of a Single X Chromosome. Med Hypotheses (2009) 72:322-4. doi: 10.1016/ j.mehy.2008.08.027

133. Spolarics Z. The X-Files of Inflammation: Cellular Mosaicism of X-Linked Polymorphic Genes and the Female Advantage in the Host Response to Injury and Infection. Shock (2007) 27:597-604. doi: 10.1097/ SHK.0b013e31802e40bd

134. Koçar IH, Yesilova Z, Ozata M, Turan M, Sengül A, Ozdemir I. The Effect of Testosterone Replacement Treatment on Immunological Features of Patients With Klinefelter's Syndrome. Clin Exp Immunol (2000) 121:448-52. doi: 10.1046/j.1365-2249.2000.01329.x

135. Cacciari E, Masi M, Fantini MP, Licastro F, Cicognani A, Pirazzoli P, et al. Serum Immunoglobulins and Lymphocyte Subpopulations Derangement in Turner's Syndrome. Int J Immunogenetics (1981) 8:337-44. doi: 10.1111/ j.1744-313X.1981.tb00938.x

136. Bianchi I, Lleo A, Gershwin ME, Invernizzi P. The X Chromosome and Immune Associated Genes. J Autoimmun (2012) 38:J187-192. doi: 10.1016/ j.jaut.2011.11.012

137. Pisitkun P, Deane JA, Difilippantonio MJ, Tarasenko T, Satterthwaite AB, Bolland S. Autoreactive B Cell Responses to RNA-Related Antigens Due to TLR7 Gene Duplication. Science (2006) 312:1669-72. doi: 10.1126/ science. 1124978

138. Karnam G, Raaben M, Grinwis GC, Coenjaerts FE, Ressing ME, et al. CD200 Receptor Controls Sex-Specific TLR7 Responses to Viral Infection. PloS Pathog (2012) 8(5):e1002710. doi: 10.1371/journal.ppat.1002710

139. Souyris M, Cenac C, Azar P, Daviaud D, Canivet A, Grunenwald S, et al. TLR7 Escapes X Chromosome Inactivation in Immune Cells. Sci Immunol (2018) 3. doi: 10.1126/sciimmunol.aap 8855

140. Souyris M, Mejía JE, Chaumeil J, Guéry J-C. Female Predisposition to TLR7Driven Autoimmunity: Gene Dosage and the Escape From X Chromosome Inactivation. Semin Immunopathol (2019) 41:153-64. doi: 10.1007/s00281018-0712-y

141. Browne EP. Regulation of B-Cell Responses by Toll-Like Receptors. Immunology (2012) 136:370-9. doi: 10.1111/j.1365-2567.2012.03587.x

142. Fink AL, Engle K, Ursin RL, Tang W-Y, Klein SL. Biological Sex Affects Vaccine Efficacy and Protection Against Influenza in Mice. PNAS (2018) 115:12477-82. doi: 10.1073/pnas.1805268115

143. van der Made CI, Simons A, Schuurs-Hoeijmakers J, van den Heuvel G, Mantere T, Kersten S, et al. Presence of Genetic Variants Among Young Men With Severe COVID-19. JAMA (2020) 324:1-11. doi: 10.1001/ jama.2020.13719

144. Pinheiro I, Dejager L, Libert C. X-Chromosome-Located microRNAs in Immunity: Might They Explain Male/Female Differences? The X Chromosome-Genomic Context may Affect X-Located miRNAs and Downstream Signaling, Thereby Contributing to the Enhanced Immune Response of Females. Bioessays (2011) 33:791-802. doi: 10.1002/ bies.201100047

145. Sharma S, Eghbali M. Influence of Sex Differences on microRNA Gene Regulation in Disease. Biol Sex Differ (2014) 5:3. doi: 10.1186/2042-6410-5-3

146. Ghorai A, Ghosh U. miRNA Gene Counts in Chromosomes Vary Widely in a Species and Biogenesis of miRNA Largely Depends on Transcription or Post-Transcriptional Processing of Coding Genes. Front Genet (2014) 5:100. doi: $10.3389 /$ fgene.2014.00100

147. Spach KM, Blake M, Bunn JY, McElvany B, Noubade R, Blankenhorn EP, et al. Cutting Edge: The Y Chromosome Controls the Age-Dependent
Experimental Allergic Encephalomyelitis Sexual Dimorphism in SJL/J Mice. J Immunol (2009) 182:1789-93. doi: 10.4049/jimmunol.0803200

148. Case LK, Teuscher C. Y Genetic Variation and Phenotypic Diversity in Health and Disease. Biol Sex Dif (2015) 6:6. doi: 10.1186/s13293-015-0024-z

149. Case LK, Toussaint L, Moussawi M, Roberts B, Saligrama N, Brossay L, et al. Chromosome Y Regulates Survival Following Murine Coxsackievirus B3 Infection. G3 (Bethesda) (2012) 2:115-21. doi: 10.1534/g3.111.001610

150. Krementsov DN, Case LK, Dienz O, Raza A, Fang Q, Ather JL, et al. Genetic Variation in Chromosome Y Regulates Susceptibility to Influenza A Virus Infection. PNAS (2017) 114:3491-6. doi: 10.1073/pnas.1620889114

151. Crowe CR, Chen K, Pociask DA, Alcorn JF, Krivich C, Enelow RI, et al. Critical Role of IL-17RA in Immunopathology of Influenza Infection. J Immunol (2009) 183:5301-10. doi: 10.4049/jimmunol.0900995

152. Baynam G, Zhang G, Khoo S-K, Sly P, Holt P, Goldblatt J, et al. GenderSpecific Effects of Cytokine Gene Polymorphisms on Childhood Vaccine Responses. Vaccine (2008) 26:3574-9. doi: 10.1016/j.vaccine.2008.05.011

153. Dumanski JP, Halvardson J, Davies H, Rychlicka-Buniowska E, Mattisson J, Moghadam B. Immune Cells Lacking Y Chromosome Have Widespread Dysregulation of Autosomal Genes. Cell Mol Life Sci (2020) 78(8):4019-33. doi: 10.1007/s00018-021-03822-w

154. Jacobs PA, Brunton M, Court Brown WM, Doll R, Goldstein H. Change of Human Chromosome Count Distributions With Age: Evidence for a Sex Difference. Nature (1963) 197:1080-1. doi: 10.1038/1971080a0

155. Thompson DJ, Genovese G, Halvardson J, Ulirsch JC, Wright DJ, Terao C, et al. Genetic Predisposition to Mosaic Y Chromosome Loss in Blood. Nature (2019) 575:652-7. doi: 10.1038/s41586-019-1765-3

156. Khulan B, Cooper WN, Skinner BM, Bauer J, Owens S, Prentice AM, et al. Periconceptional Maternal Micronutrient Supplementation Is Associated With Widespread Gender Related Changes in the Epigenome: A Study of a Unique Resource in the Gambia. Hum Mol Genet (2012) 21:2086-101. doi: $10.1093 / \mathrm{hmg} / \mathrm{dds} 026$

157. Jensen KJ, Fisker AB, Andersen A, Sartono E, Yazdanbakhsh M, Aaby P, et al. The Effects of Vitamin A Supplementation With Measles Vaccine on Leucocyte Counts and In Vitro Cytokine Production. Br J Nutr (2016) 115:619-28. doi: 10.1017/S0007114515004869

158. Bale TL. The Placenta and Neurodevelopment: Sex Differences in Prenatal Vulnerability. Dialogues Clin Neurosci (2016) 18:459-64. doi: 10.31887/ DCNS.2016.18.4/tbale

159. Mandal M, Marzouk AC, Donnelly R, Ponzio NM. Preferential Development of Th17 Cells in Offspring of Immunostimulated Pregnant Mice. J Reprod Immunol (2010) 87:97-100. doi: 10.1016/j.jri.2010.06.156

160. Boulanger-Bertolus J, Pancaro C, Mashour GA. Increasing Role of Maternal Immune Activation in Neurodevelopmental Disorders. Front Behav Neurosci (2018) 12:230. doi: 10.3389/fnbeh.2018.00230

161. Goldenberg RL, Andrews WW, Faye-Petersen OM, Goepfert AR, Cliver SP, Hauth JC. The Alabama Preterm Birth Study: Intrauterine Infection and Placental Histologic Findings in Preterm Births of Males and Females Less Than 32 Weeks. Am J Obstet Gynecol (2006) 195:1533-7. doi: 10.1016/ j.ajog.2006.05.023

162. Liu C-A, Wang C-L, Chuang H, Ou C-Y, Hsu T-Y, Yang KD. Prediction of Elevated Cord Blood IgE Levels by Maternal IgE Levels, and the Neonate's Gender and Gestational Age. Chang Gung Med J (2003) 26:561-9.

163. Sinha A, Madden J, Ross-Degnan D, Soumerai S, Platt R. Reduced Risk of Neonatal Respiratory Infections Among Breastfed Girls But Not Boys. Pediatrics (2003) 112:e303. doi: 10.1542/peds.112.4.e303

164. Forest MG, Cathiard AM, Bertrand JA. EVIDENCE OF TESTICULAR ACTIVITY IN EARLY INFANCY. J Clin Endocrinol Metab (1973) 37:148-51. doi: 10.1210/jcem-37-1-148

165. Zager A, Pinheiro ML, Ferraz-de-Paula V, Ribeiro A, Palermo-Neto J. Increased Cell-Mediated Immunity in Male Mice Offspring Exposed to Maternal Immune Activation During Late Gestation. Int Immunopharmacol (2013) 17:633-7. doi: 10.1016/j.intimp.2013.08.007

166. Onore CE, Schwartzer JJ, Careaga M, Bennan RF, Ashwood P. Maternal Immune Activation Leads to Activated Inflammatory Macrophages in Offspring. Brain Behav Immun (2014) 38:220-6. doi: 10.1016/ j.bbi.2014.02.007

167. Mandal M, Marzouk AC, Donnelly R, Ponzio NM. Maternal Immune Stimulation During Pregnancy Affects Adaptive Immunity in Offspring to 
Promote Development of TH17 Cells. Brain Behavior Immun (2011) 25:863-71. doi: 10.1016/j.bbi.2010.09.011

168. López-Díaz Á., Ayesa-Arriola R, Crespo-Facorro B, Ruiz-Veguilla M. COVID-19 Infection During Pregnancy and Risk of Neurodevelopmental Disorders in Offspring: Time for Collaborative Research. Biol Psychiatry (2021) 89:e29-30. doi: 10.1016/j.biopsych.2020.09.011

169. Bordt EA, Shook LL, Atyeo C, Pullen KM, De Guzman RM, Meinsohn M-C. Sexually Dimorphic Placental Responses to Maternal SARS-CoV-2 Infection. bioRxiv (2021). doi: 10.1101/2021.03.29.437516

170. Norman M, Navér L, Söderling J, Ahlberg M, Hervius Askling H, Aronsson B, et al. Association of Maternal SARS-CoV-2 Infection in Pregnancy With Neonatal Outcomes. JAMA (2021) 325(20):2076-86. doi: 10.1001/ jama.2021.5775

171. Allotey J, et al. Clinical Manifestations, Risk Factors, and Maternal and Perinatal Outcomes of Coronavirus Disease 2019 in Pregnancy: Living Systematic Review and Meta-Analysis. BMJ (2020) 370:m3320. doi: 10.1136/bmj.m3320

172. Liu T, Balzano-Nogueira L, Lleo A, Conesa A. Transcriptional Differences for COVID-19 Disease Map Genes Between Males and Females Indicate a Different Basal Immunophenotype Relevant to the Disease. Genes (Basel) (2020) 11:E1447. doi: 10.1101/2020.09.30.321059

173. Shapiro JR, Klein SL, Morgan R. Stop 'Controlling' for Sex and Gender in Global Health Research. BMJ Global Health (2021) 6:e005714. doi: 10.1136/ bmjgh-2021-005714
174. Potluri T, Engle K, Fink AL, vom Steeg LG, Klein SL. Sex Reporting in Preclinical Microbiological and Immunological Research. mBio (2017) 8(6): e01868-17. doi: $10.1128 / \mathrm{mBio} .01868-17$

175. Rushovich T, Boulicault M, Chen JT, Danielsen AC, Tarrant A, Richardson SS, et al. Sex Disparities in COVID-19 Mortality Vary Across US Racial Groups. J Gen Intern Med (2021) 36(6):1696-701. doi: 10.1007/s11606-02106699-4

Conflict of Interest: The authors declare that the research was conducted in the absence of any commercial or financial relationships that could be construed as a potential conflict of interest.

Publisher's Note: All claims expressed in this article are solely those of the authors and do not necessarily represent those of their affiliated organizations, or those of the publisher, the editors and the reviewers. Any product that may be evaluated in this article, or claim that may be made by its manufacturer, is not guaranteed or endorsed by the publisher.

Copyright $\odot 2021$ Jacobsen and Klein. This is an open-access article distributed under the terms of the Creative Commons Attribution License (CC BY). The use, distribution or reproduction in other forums is permitted, provided the original author(s) and the copyright owner(s) are credited and that the original publication in this journal is cited, in accordance with accepted academic practice. No use, distribution or reproduction is permitted which does not comply with these terms. 